\title{
Isolation and characterization of porcine epidemic diarrhea virus associated with the 2014 disease outbreak in Mexico: case report
}

María Elena Trujillo-Ortega', Rolando Beltrán-Figueroa', Montserrat Elemi García-Hernández², Mireya Juárez-Ramírez ${ }^{3}$, Alicia Sotomayor-González ${ }^{1}$, Erika N. Hernández-Villegas², José F. Becerra-Hernández ${ }^{2}$ and Rosa Elena Sarmiento-Silva ${ }^{2^{*}}$

\begin{abstract}
Background: Interest in porcine epidemic diarrhea has grown since the 2013 outbreak in the United States caused major losses, with mortality rates up to $100 \%$ in suckling piglets. In Mexico, an outbreak of porcine epidemic diarrhea, characterized by $100 \%$ mortality in piglets, began in March 2014 in the State of Mexico.

Methods: The aim of this study was to confirm and identify porcine epidemic diarrhea virus (PEDV) in samples from piglets with suggestive clinical signs using virological, histological, and molecular techniques. Necropsy was performed on 13 piglets from two litters with initial and advanced clinical signs. Suggestive lesions of acute infection with PEDV were detected in histological sections of the small and large bowels; specifically, multiple virus particles with visible crown-shaped projections were observed using electron microscopy and negative staining. Viral isolation was performed in Vero cells with trypsin. Infection was monitored by observation of cytopathic effect, and titration was determined by $T C I D_{50} / \mathrm{ml}$. The presence of the PEDV in cultures and clinical samples was confirmed by RT-PCR amplification and sequencing of a 651-bp segment of the $S$ glycoprotein gene, as well as a 681-bp matrix protein gene.
\end{abstract}

Results: The nucleotide sequence analysis of the Mexican isolates showed marked homology to viruses that circulated in 2013 in Colorado, USA.

Conclusions: In this paper we confirm the isolation and characterization of PEDV from animals with early and advanced clinical signs.

Keywords: Porcine epidemic diarrhea virus, Mexico, Outbreak, Characterization

\section{Background}

Recently, there has been a growing interest in porcine epidemic diarrhea (PED), stemming from the major losses caused by the 2013 outbreak in the United States, with mortality rates up to $100 \%$ in suckling piglets [1-5]. The infectious agent causing the outbreak was identified on May 10, 2013, at the Veterinary Diagnostic Laboratory of Iowa State University in Ames. Infection by

\footnotetext{
*Correspondence: rosass@unam.mx

2Departamento de Microbiología e Inmunología, Facultad de Medicina

Veterinaria y Zootecnia, Universidad Nacional Autónoma de México, Mexico

City 04510, Mexico

Full list of author information is available at the end of the article
}

a coronavirus-like virus, known as porcine epidemic diarrhea virus (PEDV), was confirmed [6, 7].

The disease first obtained recognition as a devastating enteric disorder affecting pigs in the UK in 1971. However, it wasn't until 1978, in Belgium, that the etiologic agent was identified as a coronavirus and given the name PEDV (PEDV strain CV777). While the disease was first reported in the United Kingdom in 1970, it has since then spread to Belgium, Hungary, Korea, Italy, Thailand, Japan, and China. In Asia, PED has been considered endemic since 1982, causing substantial economic losses to the swine industry $[6,8-10]$. 
PEDV is an Alphacoronavirus classified in the subfamily Coronavirinae of the family Coronaviridae. PEDV is an enveloped, single-stranded, positive sense RNA virus that infects swine, usually causing respiratory and gastrointestinal disease $[2,8,9,11]$. The complete genomic sequence of PEDV has a length of 28,038 nucleotides (nt) starting with a $292 \mathrm{nt}$ untranslated region (UTR), followed by six genes-replicase (Rep), spike (S), ORF3, envelope (E), membrane $(\mathrm{M})$, and nucleoprotein $(\mathrm{N})$ - and ending with a 3'untranslated region from 27706 to $28038 \mathrm{nt}$ [9].

PEDV infects the epithelium of the small intestine, an environment rich in proteases, and causes atrophy of the villi resulting in diarrhea and dehydration. Therefore, this disease is characterized, as its name implies, by diarrhea, often watery, as well as some systemic signs such as vomiting, fever, anorexia, and lethargy. The disease is more severe in suckling piglets because of their increased susceptibility to dehydration, but outbreaks are also observed in growing pigs and occasionally in adults [12].

In terms of diagnosis of PEDV infection, there are reports of veterinary diagnostic laboratories that have developed molecular detection techniques. However, viral isolation in cell culture remains the confirmatory test. This procedure is considered difficult to perform due to specific conditions required by the virus, such as trypsin supplementation $[6,13]$.

Although there have been studies describing the disease in the United States and Canada, to our knowledge, this is the first report of PEDV in Mexico [1, 10, 14]. The aim of this study was to isolate, identify, and characterize PEDV from samples collected during an outbreak that occurred in Mexico in 2014.

\section{Methods}

The outbreak began on March 22, 2014, and samples were taken two days after. Directed sampling was performed in pigs in the weaning phase experiencing diarrhea, vomiting, and dehydration that caused $100 \%$ mortality in piglets with permission of the owner. On April 2, samples of lung, gastric contents, stomach, intestine (duodenum), and intestinal contents (feces) were taken from 5 piglets in a litter with early clinical signs (litter $1, \mathrm{ID} \mathrm{C} 1,6 \mathrm{~h}$ of age), and five piglets in a litter with advanced clinical signs (litter 2, ID C2, 24-36 h of age). Euthanasia of both litters was performed by electrocution and subsequent exsanguination (AVMA Guidelines for the Euthanasia of Animals: 2013 Edition). In addition, two samples (lung, gastric contents, stomach, and duodenum) from dead piglets (RIP1 and RIP2) that were $36-48 \mathrm{~h}$ old at the time of death, as well as feces from two finishing pigs with diarrhea, were taken.

\section{Histopathology}

Samples of lung, stomach, small intestine (duodenum, jejunum and ileum), large intestine (cecum and colon), and mesenteric lymph nodes were collected and preserved in
$10 \%$ formalin buffered at $\mathrm{pH}$ 7.2. These samples were subsequently processed by routine paraffin embedding technique and staining with hematoxylin and eosin [15]. Tissues were evaluated using Leica DM500 optical microscopy.

\section{Transmission electron microscopy}

Fragments of small intestine (jejunum) were fixed in $2.5 \%$ glutaraldehyde for $24 \mathrm{~h}$, washed with a cacodylate solution buffered to $\mathrm{pH}$ 7.2. Then were treated with $1 \%$ osmium tetroxide, and washed with collected cacodylate buffer. Subsequently, they were dehydrated with increasing concentrations of acetone and embedded in epoxy resin. Semithin sections $(200 \mathrm{~nm})$ were cut and mounted on slides and contrasted with toluidine blue. Finally, fine cuts of $60 \mathrm{~nm}$ were mounted on copper grids and contrasted with uranyl acetate and lead citrate for posterior observation and evaluation in a Zeiss EM 900 electron microscope.

\section{Viral isolation}

Pools of samples including stool and bowel from litter 1 (advanced clinical signs), and litter 2 (initial clinical signs) were macerated by adding $5 \mathrm{ml}$ of D-MEM (Gibco Cat. 10313-021 Lot. 1374740) in the presence of antibiotics (Penicillin $10.00 \mathrm{U} / \mathrm{ml}$, streptomycin 10,000 mcg/ml Gibco Cat. 15140-122 and $200 \mathrm{mM}$ L-glutamine, Gibco 25030081), and centrifuged at $1500 \mathrm{rpm}$ for $10 \mathrm{~min}$. The supernatant was filtered using a Millex GP filter unit, $0.22 \mu \mathrm{m}$ (Millipore Express PES membrane, Cat. SLGP033RB).

Vero cells were grown in six-well plates (Corning Inc. COSTAR 3527) previously washed with D-MEM (5 times) to remove the fetal bovine serum. These plates were then inoculated with filtered supernatants in D-MEM supplemented with different concentrations of trypsin $(2.5,5,10$, and $20 \mu \mathrm{g} / \mathrm{ml}$, and $2 \mathrm{mg} / \mathrm{ml}$ ) (DifcoTripsine 250 Cat. 215240, Lot. 4181462). After $2 \mathrm{~h}$, this material was removed and the plates were filled with fresh complete medium containing trypsin.

At $48 \mathrm{~h}$ post-infection the cells were resuspended, collected, sonicated for $5 \mathrm{~min}$ at $37{ }^{\circ} \mathrm{C}$ (BransonicSonifier, 5510 Ultrasonic cleaner), and centrifuged at $5000 \mathrm{rpm}$. An aliquot of $500 \mu \mathrm{l}$ was collected for posterior RNA extraction. The remaining supernatant was used to infect serial passages in Vero cells in the above conditions (Passage 2).

Supernatant titrations were performed with $\mathrm{TCID}_{50} /$ $\mathrm{ml}$, using Reed \& Münch formula [16].

\section{RT-PCR}

\section{RNA extraction}

RNA extraction from different passages of the supernatants and samples (intestine, feces, gastric contents, stomach) was achieved with Trizol reagent according to the manufacturer's instructions (Gibco Life Technologies Cat. 15596-018). Table 1 shows the conditions used in the one step RT-PCR reaction. 
Table 1 Conditions used for the RT-PCR

\begin{tabular}{llllll}
\hline ID & Gene & Sequence & Position & Tm $^{\circ} \mathrm{C}$ & Amplicon size \\
\hline PEDVF (1) & $S^{a}$ & TTCTGAGTCACGAACAGCCA & 1,466 & 55 & 651 \\
PEDVR (1) & $S^{a}$ & CATATGCAGCCTGCTCTGAA & 2,097 & 55 & 651 \\
MPED2F (2) & $M^{b}$ & AGTCTTACATGCGAATTGACC & 2,565 & 55 & 681 \\
MPED2R (2) & $M^{b}$ & AGCTGACAGAAGCCATAAAGT & 2,398 & 55 & 681 \\
\hline
\end{tabular}

${ }^{\mathrm{a}}[20],{ }^{\mathrm{b}}[21]$

\section{RT-PCR conditions}

RT-PCR reaction was performed using Onestep Kit (Qiagen Cat. 210212) with some variations for a total $20 \mu$ reaction mixture: $4 \mu \mathrm{l} 5 \times$ Buffer, dNTPs $0.8 \mu \mathrm{l}$, $0.8 \mu$ l Primer, $0.8 \mu$ l Primer $\mathrm{R}, 0.8 \mu$ l enzyme mixture, $0.4 \mu \mathrm{l}$ RNase inhibitor, $7.4 \mathrm{l}$ of $\mathrm{H}_{2} \mathrm{O}$, and $5.0 \mu \mathrm{l}$ of RNA.

The thermocycler was preheated to $50{ }^{\circ} \mathrm{C}$ for $2 \mathrm{~min}$, after which the reaction tubes were placed, reverse transcription was carried out at $50{ }^{\circ} \mathrm{C}$ for $30 \mathrm{~min}$, and reverse transcriptase was inactivated for $15 \mathrm{~min}$ at $95{ }^{\circ} \mathrm{C}$. The reaction was carried out under the following conditions: $94{ }^{\circ} \mathrm{C} 2 \mathrm{~min},\left(94{ }^{\circ} \mathrm{C} 1 \mathrm{~min}, 55^{\circ} \mathrm{C} 1 \mathrm{~min}, 72{ }^{\circ} \mathrm{C} 90 \mathrm{~min}\right.$ ) for 40 cycles, with a final period of $10 \mathrm{~min}$ at $72{ }^{\circ} \mathrm{C}$. Selected primers and their specifications are shown in Table 1.

In order to confirm the presence of viral antigens and to discard the possibility of TGEV and rotavirus infection, Immunochromatography in Sandwich PEDV Ag (Bionote PED Ag Cat. RG14-01), TGE Ag (Bionote TEG/PED Ag Cat. RG14-03), and Rotavirus Ag test (Bionote PED/ ROTA Ag Cat. RG14-05) were performed according to manufacturer instructions in gastric content, feces, lung, and intestine samples of one litter as well as in cell culture supernatant of VERO infected cells.

\section{Sequencing}

The amplification products were purified by SE-Gel ${ }^{\oplus} 2 \%$ (Size Select Agarose Gels ${ }^{\mathrm{Tm}}$, Invitrogene Cat. G6610-02) according to the manufacturer's protocol and sequenced by the Sanger method using ABI 3130 platform Sequencing. The sequences were edited, assembled, and aligned using Bio-Edit, Clone Manager Version 9, MultAlin 5.4.1, and MEGA6 programs.

\section{Results}

\section{Gross lesions}

Necropsy was performed on piglets less than one week old from two litters, all of which exhibited a body condition of $1-3 / 5$, anorexia, depression, dehydration, and watery yellow diarrhea. Postmortem examination in $20 \%$ of the piglets showed small areas of lung consolidation in the cranial lobes. The stomach was markedly dilated and full of coagulated milk. $100 \%$ of piglets exhibited small bowel dilatation and in the intestinal lumen, abundant water content and yellow coagulated milk was present (Fig. 1).

\section{Microscopic lesions}

Histological sections of lung, stomach, small intestine (duodenum, jejunum and ileum), large intestine (cecum and colon), and mesenteric lymph nodes were evaluated. In the lung, mild interstitial lymphohistiocytic infiltrate was observed; as well as neutrophilic infiltrate intraalveolar bronchiolar moderate. In the gastric mucosa, parietal cell necrosis, neutrophilic and lymphocytic infiltrate,

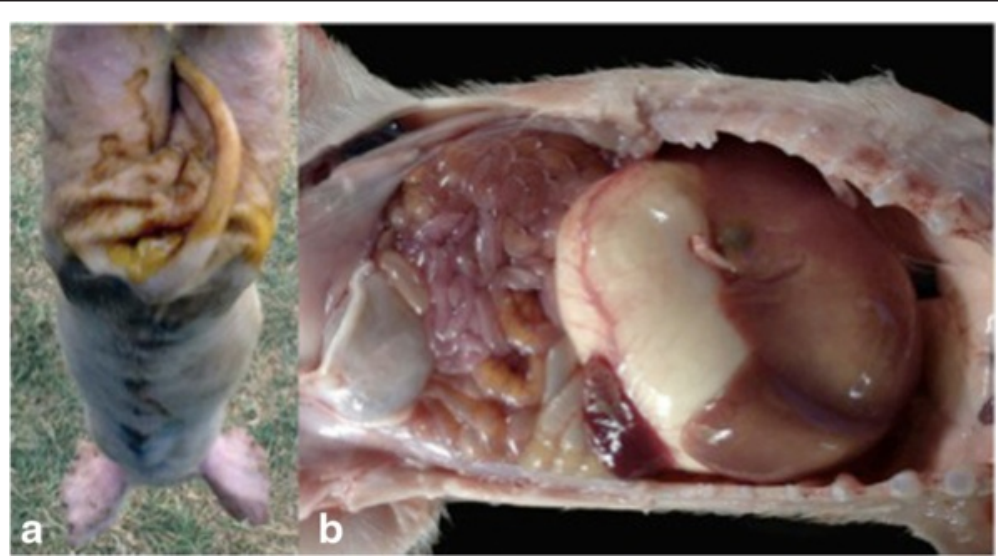

Fig. 1 a Suckling pig, 6 days old. The perianal region exhibits abundant yellow watery stools. b Abdominal cavity. The stomach is markedly dilated and full of coagulated milk. Small bowel dilatation and thinning, through which abundant yellow water content and undigested food remains can be observed 

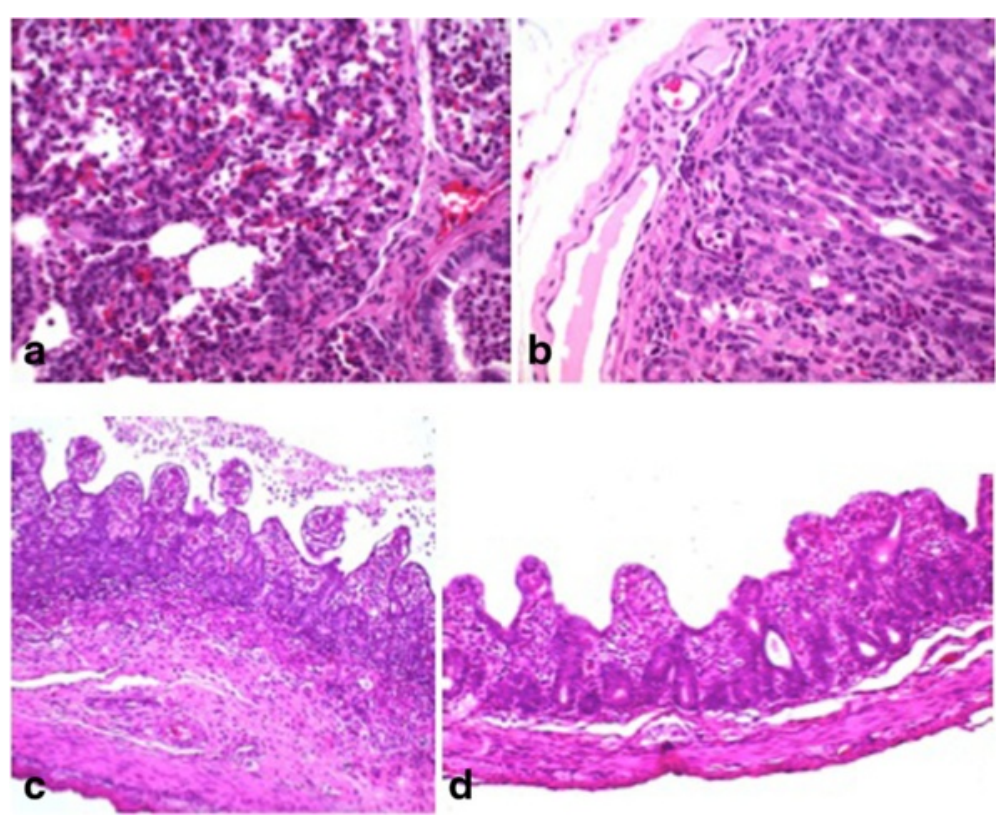

Fig. 2 a Lung. Slight lymphohistiocytic interstitial infiltrate is observed, as well as moderate neutrophilic infiltrate intra-alveolar bronchiolar. b Stomach. The gastric mucosa parietal cells exhibited necrosis and multifocal neutrophilic infiltrate with mild dilatation of lymphatic vessels. $\mathbf{c}$ and $\mathbf{d}$ Jejunum. Degeneration and necrosis of intestinal epithelial cells, severe villous atrophy, and mild to moderate lymphocytic infiltrate can be observed

and mild multifocal and dilated lymphatic vessels were seen. In histological sections of small and large intestine, degeneration and necrosis of intestinal epithelial cells, severe villous atrophy, lymphocytic infiltrate, mild to moderate congestion, and dilatation of lymphatic vessels were detected. The most significant changes were noted in the jejunum and ileum. Finally, the mesenteric lymph nodes exhibited moderate lymphoid hyperplasia (Fig. 2).

\section{Transmission electron microscopy}

Ultrastructural evaluation of the small intestine of piglets from both litters was accomplished. Enterocytes exhibited shortening and degeneration of microvilli. In the cytoplasm, the rough endoplasmic reticulum exhibited different degrees of expansion and loosening of ribosomes, and mitochondrial cristae were lost due to swelling. Numerous spherical viral particles were observed, with a size and morphology compatible with the described characteristics of coronavirus structure (Fig. 3).

\section{Viral isolation and characterization}

In the first passage, Vero infected cells with $2 \mathrm{mg} / \mathrm{ml}$ and $20 \mu \mathrm{g} / \mathrm{ml}$ of trypsin were detached, as well as uninfected cells with the same concentrations of trypsin. Infected cells treated with $2.5,5$, and $10 \mu \mathrm{g}$ of trypsin showed cytopathic effect (CPE), which consists of rounded cells, small plaques, intracytoplasmic vacuoles, and detachment not observed in uninfected cells. The effect was observed $24 \mathrm{~h}$ post-infection in cells infected with samples from litter 2 .
For subsequent passages, trypsin concentrated at $10 \mu \mathrm{g} /$ $\mathrm{ml}$ was selected, as the cells did not detach, CPE was observed, and identification by RT-PCR was positive (Fig. 4).

A total of three passages of virus isolates in Vero cells were carried out to determine whether the isolated virus

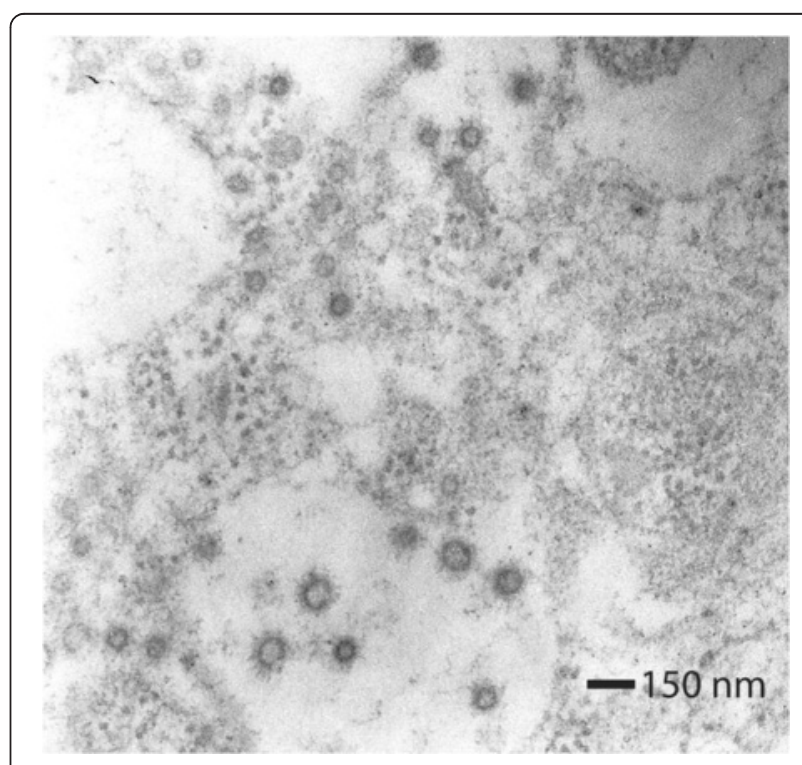

Fig. 3 Electronic transmission photography of an enterocyte's cytoplasm. Numerous viral particles measuring $75-83 \mathrm{~nm}$ in diameter are observed. These viral particles possess a membrane with numerous slightly electrodense projections that are $20 \mathrm{~nm}$ in length (arrow). Adjacent to these viral particles, clusters of ribosomes (inset) are appreciated. Contrast technique with uranyl acetate and lead citrate. 50,000x magnification 


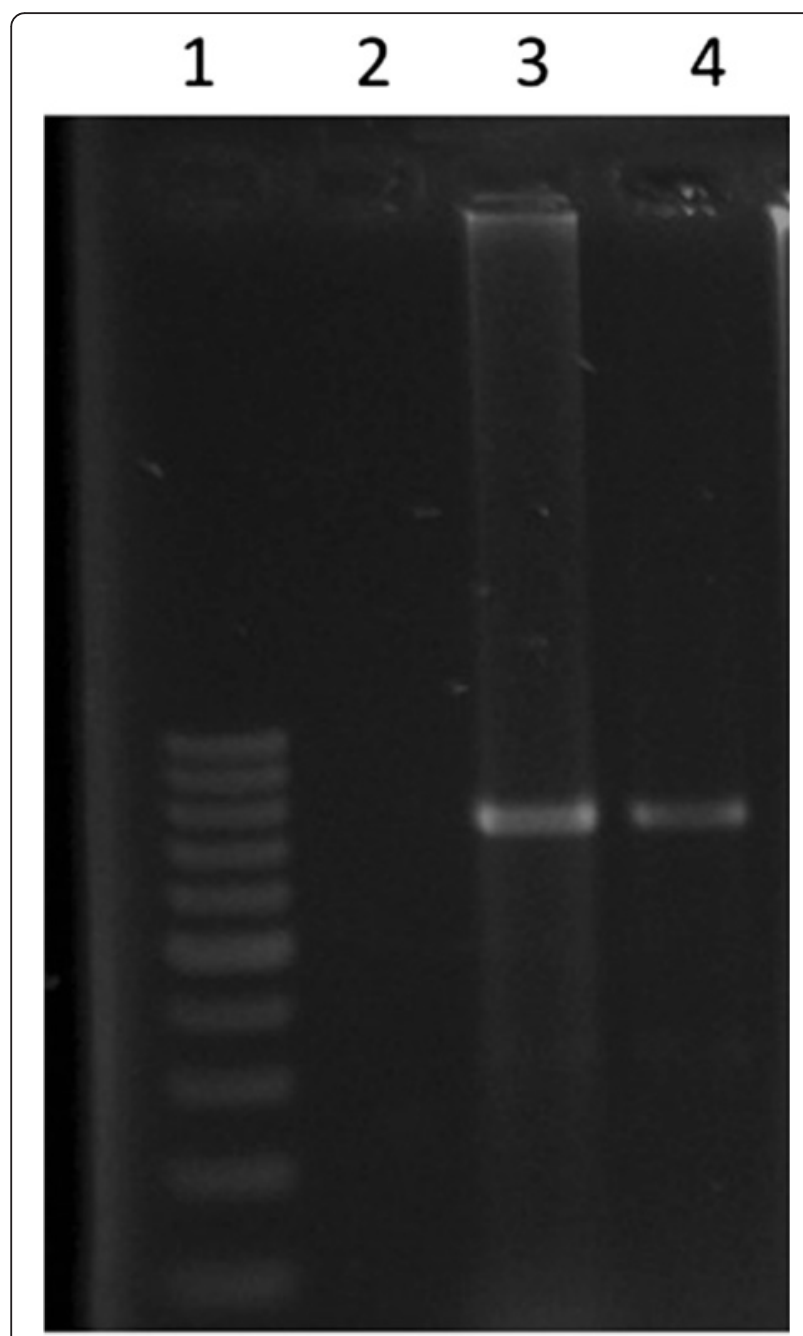

Fig. 4 RT-PCR PEDV M gene. 1. Molecular size 100-bp, 2. Vero cells

(NC), 3. RT-PCR of $M$ gene from a gastric content sample and 4. RT-PCR of $\mathrm{M}$ gene from supernatant of passage 9 of infected Vero cells could propagate and survive efficiently in cell culture. A clear CPE was observed after $24 \mathrm{~h}$ post-infection. Figure 5 shows a representative effect from passage nine after $24 \mathrm{~h}$ post-infection. During these passages the title of infectious virus fluctuated between $2.32 \mathrm{E}+03$ and $2.81 \mathrm{E}+$ $06 \mathrm{TCID}_{50} / \mathrm{ml}$.

\section{Molecular diagnosis $R T-P C R$ in clinical samples}

The $S$ gene fragment of 651-bp was amplified with PEDVF and PEDVR primers, (Table 1) while the primers MPED2F and MPED2R amplified a $M$ gene fragment of 681-bp. Table 2 summarizes RT-PCR results in different types of samples, as well as direct Immunochromatography in Sandwich results of PED, TGE, and Rotavirus Ag tests, confirming the presence of PEDV and the absence of TGEV and porcine rotavirus antigens.

\section{Nucleotide sequence accession numbers}

The 4 partial sequences of each gene ( $\mathrm{M}$ and $\mathrm{S}$ ) were deposited in GenBank under accession numbers KM044328, KM044329, KM044330, KM044331, KM044332, KM044333, KM044334, and KM044335, respectively.

Molecular analysis was completed with partial amplifications of $\mathrm{S}$ and $\mathrm{M}$ viral genes; the sequences obtained for S gene (593-bp) showed $99 \%$ similarity with the same region of the strains NPL-PEDV/2013/P10 (KJ778616, Lawrence PK unpublished date May 2014), K13JA11-4 (KJ539153, Cho, YY. 2014), and OH14 (access No. KJ408801). For M gene (681-bp) $95 \%$ similarity was found with strains NPL-PEDV/2013/P10 (KJ778616 [17], OH14 (access No. KJ408801), and USA/Indiana/17846/2013 (Access No. KF452323) (Fig. 6) [18].

\section{Discussion}

Enteric diseases in piglets cause severe losses in the swine industry. Infectious agents commonly involved are Escherichia coli, Clostridium perfringens type C, Isospora suis, rotavirus, and coronavirus (TGEV and PEDV).

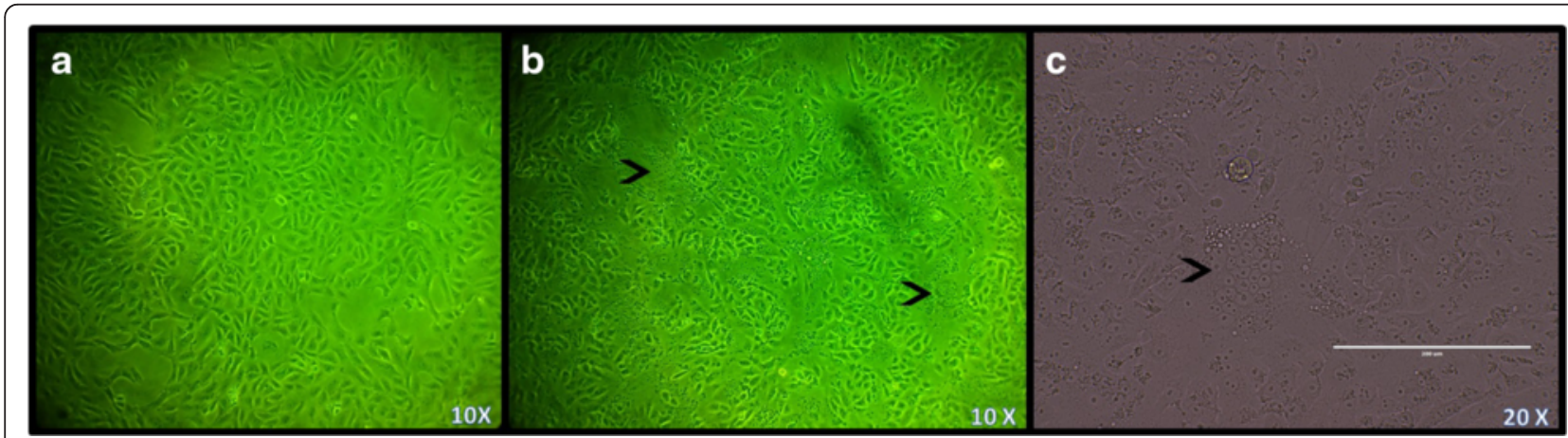

Fig. 5 CPE representative effect from passage 9 after $24 \mathrm{~h}$ post-infection. a Negative control 10x. b Passage 9 from Vero cells infected with gastric content 10x. and c Passage 9 from Vero cells infected with gastric content 20x 
Table 2 Summary of RT-PCR results for the amplification of fragments $M$ and S from different tissues and Immunochromatography in Sandwich PEDV, TGEV, and porcine rotavirus antigen (Ag)

\begin{tabular}{|c|c|c|c|c|c|c|c|c|c|c|c|c|}
\hline \multirow[t]{3}{*}{ SAMPLE } & \multicolumn{3}{|c|}{ RT-PCR M } & \multicolumn{3}{|c|}{ RT-PCR S } & \multicolumn{3}{|c|}{ ISOLATE } & \multicolumn{3}{|l|}{ Ag test } \\
\hline & & & & & & & & & & \multirow[t]{2}{*}{ Rotavirus } & \multirow[t]{2}{*}{ PEDV } & \multirow[t]{2}{*}{ TGEV } \\
\hline & $\mathrm{C} 1$ & C2 & RIP & $\mathrm{C} 1$ & C2 & RIP & $\mathrm{C} 1$ & $\mathrm{C} 2$ & RIP & & & \\
\hline STOMACH CONTENTS & + & + & + & + & + & + & & & & - & + & - \\
\hline INTESTINE & + & + & + & + & + & + & + & + & + & - & + & - \\
\hline STOMACH & + & + & + & + & + & + & & & & - & & - \\
\hline FECES & + & + & N.C. & + & + & N.C. & + & + & & - & + & - \\
\hline LUNG & - & - & - & - & - & - & & & & - & - & - \\
\hline
\end{tabular}

NC not collected

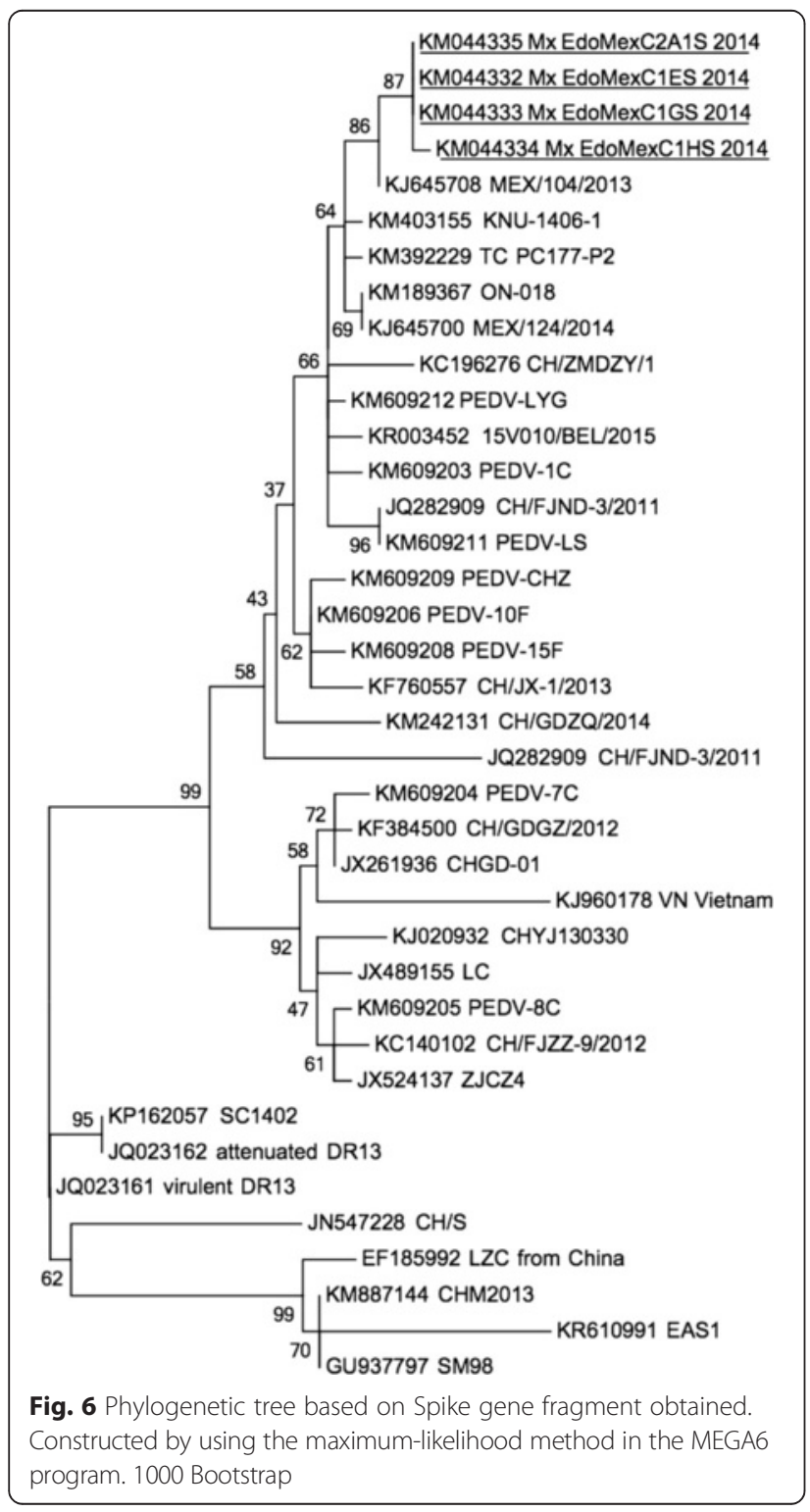

Recently, the porcine epidemic diarrhea virus (PEDV) has become highly relevant as a result of the outbreak detected in the United States in 2013 [19].

In Mexico, the National Health, Food Safety, and Food Quality Service (SENASICA), sent a notification in May 2014 to the OIE alerting the existence of suggestive clinical evidence indicating the presence of PEDV. Official veterinary services, in coordination with farmers, developed a diagnostic protocol for the disease, including epidemiological sampling of finishing, fattening, breeding stock, and backyard farm animals exhibiting clinical signs. In the research conducted from August 2013 to May 2014, 2309 samples were analyzed by Real Time PCR, of which $30 \%$ were positive. It should be noted that, until that report, authorities had not been able to isolate PEDV, so participation of other infectious agents cannot be ruled out.

In the present study, the clinical symptoms, morbidity, mortality, as well as macroscopic and microscopic lesions observed, coincided with field and experimental infections with PEDV $[2,5,7,8,12]$. Moreover, we detected the presence of viral particles compatible with coronavirus in jejunal enterocytes using transmission electron microscopy. These findings, along with the absence of histopathological evidence of bacterial and parasitic pathogens such as Escherichia coli, Clostridium perfringens type C, and Isospora suis, allowed us to discard possible differential diagnoses to TGEV and porcine rotavirus, which were ruled out using the antigen detection test.

This is the first study reporting isolation of PEDV from the outbreak in Mexico. Isolation from intestine and fecal samples of two litters of animals with initial and advanced clinical signs was achieved using several concentrations of trypsin: $2.5,5,10,20 \mu \mathrm{g} / \mathrm{ml}$, and $2 \mathrm{mg} / \mathrm{ml}$. Uninfected cells treated with $20 \mu \mathrm{g} / \mathrm{ml}$ and $2 \mathrm{mg} / \mathrm{ml}$ detached from all culture bottles; 5 and $10 \mu \mathrm{g} / \mathrm{ml}$ treated cells remained attached allowing observation of cytopathic effect after $24 \mathrm{~h}$ post-infection. These results show that using a lower quantity of trypsin $(15 \mu \mathrm{g} / \mathrm{ml})$ than reported in other studies still allows the virus to infect the target cells [13]. 
RT-PCR was performed to confirm the presence of the virus in cell culture with the amplification of viral genes $\mathrm{S}$ and M as reported by Kim et al. (2001) and Li et al. (2012), with observation of expected amplification products throughout all passages [20, 21]. Likewise, titration of each passage was obtained via $\mathrm{TCID}_{50} / \mathrm{ml}$. Titers ranging between $2.32 \times 10^{3}$ and $2.81 \times 10^{6} \mathrm{TCID}_{50} / \mathrm{ml}$ demonstrate progressive replication throughout serial passages.

PEDV isolation represents an important tool for the investigation of its pathogenesis, as well as for the development of serological and molecular diagnostic techniques. A standardized technique for PEDV propagation is essential for potential development of an attenuated vaccine that could be used in nursery pigs and pregnant sows to mitigate the negative impact caused by the disease.

\section{Conclusions}

The pigs described in this study already showed clinical signs consistent with the PEDV infection as we demonstrated by differential diagnosis and in this paper we confirm the isolation and characterization of PEDV from animals with early and advanced clinical signs.

\section{Abbreviations}

AVMA, American Veterinary Medical Association; CPE, cytopathic effect; OIE, World Organization for Animal Health; PCR, polymerase chain reaction; PED, porcine epidemic diarrhea; $R T$, reverse transcriptase; TGE, transmissible gastroenteritis

\section{Acknowledgments}

Viral isolation advice was given by Eric Nelson, Ph.D. (Veterinary \& Biomedical Sciences, South Dakota State University, EE. UU.). Phylogenetic study advice was given by Fernando González Candelas, PhD. (University of Valencia, Spain). Samples were obtained with the help of the Teaching and Research Center in Swine Production (CEIEPP, Centro de Enseñanza e Invesigación en Producción Porcina), FMVZ, UNAM, and Javier Díaz Castorena for help with references assistance.

\section{Funding}

This study was financially supported by PAPIIT project No. IN220515; Modulation of the Concentration of Acute Phase Proteins in pigs immunized with Mexican isolates of Porcine Epidemic Diarrhea virus and its association with antigenic variation.

\section{Availability of data and materials}

All data is presented in this manuscript and available upon request. Nucleotide sequence data reported is available in the GenBank database under accession numbers KM044328, KM044329, KM044330, KM044331, KM044332, KM044333, KM044334, and KM044335.

\section{Authors' contributions}

RESS directed the research, reviewed the data and manuscript; and directed revisions. METO conducted research and compiled data. RBF was involved in sampling and phylogenetic analysis and participated in drafting the manuscript. MJR provided pathological analysis and participated in drafting the manuscript. MEGH was involved in the development of molecular techniques and phylogenetic analysis and participated in drafting the manuscript; ASG, ENHV and JFBH performed viral isolation and the manuscript draft. All authors have read and approved the manuscript.

\section{Competing interests}

The authors declare that they have no competing interests.
Consent for publication

Not applicable.

\section{Ethics approval and consent to participate}

This study was approved by the author's institution (Centro de Enseñanza, Investigación y Extensión en Producción Porcina, CEIEPP) and owner consent was obtained for the animals used for the post-mortem examinations.

\section{Author details}

'Departamento de Medicina y Zootecnia de Cerdos, Facultad de Medicina Veterinaria y Zootecnia, Universidad Nacional Autónoma de México, Mexico City 04510, Mexico. ${ }^{2}$ Departamento de Microbiología e Inmunología, Facultad de Medicina Veterinaria y Zootecnia, Universidad Nacional Autónoma de México, Mexico City 04510, Mexico. ${ }^{3}$ Departamento de Patología, Facultad de Medicina Veterinaria y Zootecnia, Universidad Nacional Autónoma de México, Mexico City 04510, Mexico.

Received: 17 January 2016 Accepted: 24 June 2016

Published online: 29 June 2016

\section{References}

1. Zhao J, Shi BJ, Huang XG, Peng MY, Zhang XM, He DN, Pang R, Zhou B, Chen PY. A multiplex RT-PCR assay for rapid and differential diagnosis of four porcine diarrhea associated viruses in field samples from pig farms in East China from 2010 to 2012. J Virol Methods. 2013;194(1-2):107-12.

2. Jung K, Saif L. Porcine epidemic diarrhea virus infection: Etiology, epidemiology, pathogenesis and immunoprophylaxis. Vet J. 2015;204(2):134-43.

3. Bowman AS, Krogwold RA, Price T, Davis M, Moeller SJ. Investigating the introduction of porcine epidemic diarrhea virus into an Ohio swine operation. BMC Vet Res. 2015:11:38.

4. Marthaler D, Bruner L, Collins J, Rossow K. Third strain of porcine epidemic diarrhea virus. United States Emerg Infect Dis. 2014;20(12):2162-3.

5. Opriessnig T. Re-emergence of porcine epidemic diarrhea virus in the global pig population. Vet J. 2015;204(2):131

6. Mole B. Deadly pig virus slips through US borders. Nature. 2013;499(7459):388.

7. Song D, Huang D, Peng Q, Huang T, Chen Y, Zhang T, Nie X, He H, Wang P, Liu Q, et al. Molecular characterization and phylogenetic analysis of porcine epidemic diarrhea viruses associated with outbreaks of severe diarrhea in piglets in Jiangxi, China 2013. PLoS One. 2015;10(3):e0120310.

8. Huang YW, Dickerman AW, Pineyro P, Li L, Fang L, Kiehne R, Opriessnig T, Meng XJ. Origin, evolution, and genotyping of emergent porcine epidemic diarrhea virus strains in the United States. MBio. 2013;4(5):e00737-00713.

9. Marthaler D, Jiang Y, Otterson T, Goyal S, Rossow K, Collins J. Complete Genome Sequence of Porcine Epidemic Diarrhea Virus Strain USA/Colorado/ 2013 from the United States. Genome Announc. 2013;1(4):e00555-13.

10. Chen Q, Li G, Stasko J, Thomas JT, Stensland WR, Pillatzki AE, Gauger PC, Schwartz KJ, Madson D, Yoon KJ, et al. Isolation and characterization of porcine epidemic diarrhea viruses associated with the 2013 disease outbreak among swine in the United States. J Clin Microbiol. 2014;52(1):234-43.

11. Su S, Wong G, Shi W, Liu J, Lai AC, Zhou J, Liu W, Bi Y, Gao GF. Epidemiology, Genetic Recombination, and Pathogenesis of Coronaviruses. Trends Microbiol. 2016;24(6):490-502.

12. Madson DM, Magstadt DR, Arruda PH, Hoang H, Sun D, Bower LP, Bhandari $M$, Burrough ER, Gauger PC, Pillatzki AE, et al. Pathogenesis of porcine epidemic diarrhea virus isolate (US/lowa/18984/2013) in 3-week-old weaned pigs. Vet Microbiol. 2014;174(1-2):60-8.

13. Wicht O, Li W, Willems L, Meuleman TJ, Wubbolts RW, van Kuppeveld FJ, Rottier PJ, Bosch BJ. Proteolytic activation of the porcine epidemic diarrhea coronavirus spike fusion protein by trypsin in cell culture. J Virol. 2014;88(14):7952-61.

14. Ojkic D, Hazlett M, Fairles J, Marom A, Slavic D, Maxie G, Alexandersen S, Pasick J, Alsop J, Burlatschenko S. The first case of porcine epidemic diarrhea in Canada. Can Vet J. 2015:56(2):149-52.

15. Prophet EB, Mills B, Arrington JB, Sobin LH. Hematoxilina y Eosina. Métodos histotecnológicos. In: Métodos histotecnológicos. Washington: Instituto de Patología de las fuerzas armadas de los Estados Unidos de América; 1995.

16. Payment $P$, Trudel M. Methods and Techniques in Virology. New York: Marcel Dekker, INC New York; 1993.

17. Lawrence PK, Bumgardner E, Bey RF, Stine D, Bumgarner RE. Genome sequences of porcine epidemic diarrhea virus: in vivo and in vitro phenotypes. Genome Announc. 2014;2(3):e00503-14. 
18. Stevenson GW, Hoang H, Schwartz KI, Burrough ER, Sun D, Madson D, Cooper VL, Pillatzki A, Gauger P, Schmitt BJ, et al. Emergence of Porcine epidemic diarrhea virus in the United States: clinical signs, lesions, and viral genomic sequences. J Vet Diagn Invest. 2013;25(5):649-54.

19. Crawford K, Lager K, Miller L, Opriessnig T, Gerber P, Hesse R. Evaluation of porcine epidemic diarrhea virus transmission and the immune response in growing pigs. Vet Res. 2015;46(1):49.

20. Kim SY, Song DS, Park BK. Differential detection of transmissible gastroenteritis virus and porcine epidemic diarrhea virus by duplex RT-PCR. J Vet Diagn Invest. 2001;13(6):516-20.

21. Li ZL, Zhu L, Ma JY, Zhou QF, Song YH, Sun BL, Chen RA, Xie QM, Bee YZ Molecular characterization and phylogenetic analysis of porcine epidemic diarrhea virus (PEDV) field strains in south China. Virus Genes. 2012;45(1):181-5.

Submit your next manuscript to BioMed Central and we will help you at every step:

- We accept pre-submission inquiries

- Our selector tool helps you to find the most relevant journal

- We provide round the clock customer support

- Convenient online submission

- Thorough peer review

- Inclusion in PubMed and all major indexing services

- Maximum visibility for your research

Submit your manuscript at www.biomedcentral.com/submit
Biomed Central 